\title{
Our Remaining Options for Preventing a Nuclear Iran
}

\author{
Thomas D. MacDonald ${ }^{1, *}$, Peter Roemer ${ }^{2}$, Ethan Klein ${ }^{1}$ \\ Edited by Madeline P. Hoffman and Anthony Tabet
}

\section{HIGHLIGHTS}

- The Iran nuclear deal placed meaningful limitations on Iran's ability to develop a nuclear weapon over the next decade.

- The International Atomic Energy Agency has continuously verified Iranian compliance with the deal, despite separate serious concerns regarding undeclared nuclear sites.

- Since withdrawing from the deal, U.S. options to curtail Iranian proliferation include (i) unilateral employment of economic sanctions, (ii) direct military action, and (iii) return to a diplomatic agreement.

- Returning to a cooperative agreement such as the Iran deal, though made challenging by mutual distrust, provides the best chance to prevent Iran from resuming a nuclear weapons program.

Fifty years ago the Treaty on the Non-Proliferation of Nuclear Weapons (NPT), an international agreement that seeks to limit the spread of nuclear weapons, went into effect. Under the NPT, all countries party to the treaty are permitted to develop nuclear technologies for peaceful activities, but countries without nuclear weapons are not permitted to divert those technologies to manufacture nuclear weapons. In 2003, it was determined that Iran had pursued nuclear weapons under the guise of its civilian nuclear program, violating its NPT commitments. Unified international economic sanctions brought Iran to the negotiating table, resulting in the Iran Deal, formally termed the Joint Comprehensive Plan of Action (JCPOA), signed in 2015. The Iran deal placed additional limits beyond NPT restrictions, on materials and activities that could be diverted to developing a nuclear weapon, extending the time needed for Iran to develop a nuclear weapon from a few months to roughly a year. This changed when the United States unilaterally withdrew from the JCPOA in May 2018 and Iran announced the following year that it would no

\footnotetext{
${ }^{1}$ Department of Nuclear Science and Engineering, Massachusetts Institute of Technology, Cambridge, MA

${ }^{2}$ Department of Earth, Atmospheric, and Planetary Sciences, Massachusetts Institute of Technology, Cambridge, MA

*Email: tdmacd@mit.edu
}

The authors declare no conflict of interest.

(C) 2020 The Author(s) longer be bound by the terms of the deal. Lacking the added restrictions of the Iran deal, Iran has begun ramping up domestic nuclear activities, raising fears that they may pursue development of a nuclear weapon. The United States has several policy options available in seeking to forestall such an outcome. This article discusses the advantages and disadvantages of several of these options, including economic sanctions, counterproliferation military action, or return to the JCPOA or a similar diplomatic agreement. The return to a cooperative agreement such as the Iran deal, though made challenging by mutual distrust, is assessed to provide the best chance to prevent Iran from resuming a nuclear weapons program.

Nuclear weapons have an immense destructive power that set them apart from conventional weapons. In the early days of the nuclear age, an arms race led to five states acquiring nuclear weapons[1]. In 1968, realizing the risks posed by the spread of nuclear weapons, the states of the United Nations established the Treaty on the Non-Proliferation of Nuclear Weapons (NPT) to prevent further nuclear proliferation. The treaty is essentially a bargain between states possessing nuclear weapons and those states without: nuclear weapons states agreed not to transfer or aid others in developing nuclear weapons and to pursue nuclear disarmament, and in exchange, the non-nuclear weapons states agreed not to pursue nuclear weapons or receive aid in acquiring them.

Efforts to limit the spread of nuclear weapons have had mixed results. Despite the NPT and other international nuclear treaties, nuclear weapons have not lost their allure to countries whose national security is precarious or to states seeking national prestige from mastering nuclear technology[2]. Several states did not sign on to the NPT and later developed nuclear weapons (i.e. India, Pakistan, and almost certainly Israel), and one state (the Democratic People's Republic of Korea) signed on to the NPT before withdrawing and testing nuclear weapons[3].

Iran was an original signatory of the NPT but in the early 2000s was found to have violated their pledge to not pursue nuclear weapons. This resulted in a concerted international response which culminated in a multi-national agreement that sought to verify Iran's return to compliance. The Joint Comprehensive Plan of Action (JCPOA), colloquially known as the "Iran Deal," was, and is, a major domestic political and national security issue in the United States. In 2018, 
the Trump administration unilaterally withdrew from the agreement and the following year Iran began to infringe on the deal's terms and exceed some if its specific limits. In this paper, we will provide the background of the Iranian nuclear program, explain what the Iran Deal was designed to do, what U.S. withdrawal from the deal and subsequent Iranian non-compliance means, and what policy options exist going forward.

\section{Nuclear Nonproliferation}

Nuclear Proliferation and the NPT The stated goals of the NPT are to "prevent the spread of nuclear weapons and weapons technology, to promote the peaceful use of nuclear energy and to further the goal of achieving nuclear disarmament." Nuclear disarmament - the reductions in the number of nuclear weapons possessed by nuclear armed states - has largely occurred on a bilateral basis between the United States and Russia, the two countries with largest number of nuclear weapons. Non-nuclear weapon states are allowed and encouraged to pursue the peaceful use of nuclear power, provided that they do not attempt to develop nuclear weapons. This creates an internal tension in the agreement, as many of the technologies which are useful to civilian nuclear power can also be used in support of a nuclear weapons program. To prevent this misuse, non-nuclear-weapon states agree to accept a set of safeguards. These are technical measures, monitored by the International Atomic Energy Agency (IAEA), which are designed to prevent and detect the development of nuclear weapons.

Building a nuclear weapon requires either plutonium or highly enriched uranium. Safeguards are designed to detect if a state attempts to accumulate enough of these materials to build a nuclear weapon by diverting them from legitimate civilian uses. Plutonium is created from uranium in a nuclear reactor, or with a particle accelerator. It exists in all of the spent nuclear fuel from the normal operation of a nuclear power plant. As such, any country with civil nuclear power could have access to plutonium. However, in order to be made usable for a weapon the plutonium must be chemically separated from the spent fuel. This can be a difficult endeavour that requires specialized infrastructure as spent fuel is highly radioactive and difficult to handle. Once separated from the fuel, only a few kilograms of plutonium are needed to build a bomb[4].

The nuclear material for a weapon can also be acquired through the uranium pathway. Uranium is a naturally occurring element that can be found in ore deposits around the world[5]. Uranium contains two main isotopes, only one of which (uranium-235) is fissile, meaning that it can sustain a nuclear chain reaction needed to power a nuclear reactor or a bomb. Natural uranium found in ore deposits is composed of more than $99 \%$ of the isotope (uranium-238) that is not fissile. Natural uranium can only be burned in specialized reactors, such as heavy water or graphite reactors, which can be easily used to produce plutonium. The Indian nuclear weapons program followed this path, modifying a Canadian-built heavy water reactor and utilizing it to make plutonium[6].

Alternatively, natural uranium can be enriched, increasing the percentage of the fissile isotope to make it easier to burn. There are many ways to enrich uranium, the most common of which is utilizing centrifuges[7]. In a gas centrifuge, uranium is converted into a gaseous form and passed through spinning centrifuges which separate out the lighter, fissile isotope uranium-235. The more work spent separating the isotopes, the higher the enrichment. Low enriched uranium (LEU) is uranium that is between $3-20 \%$ of the fissile isotope. This is the enrichment that most commercial nuclear power plants require for their fuel. For use in a weapon, highly enriched uranium (HEU), which is enriched to over $90 \%$, is required. Thus, enrichment technologies such as centrifuges are potential points where civilian infrastructure can be modified to divert material into a weapons program.

In order to monitor these pathways, the IAEA utilizes a system of safeguards[8]. These include inspection and monitoring of declared nuclear facilities, and close monitoring and accounting of nuclear materials. In countries which have accepted an agreement called the Additional Protocol, IAEA inspectors are able to make visits on short notice to any sites involved in the country's nuclear fuel cycle. They are also able to take environmental samples which can detect the presence of undeclared nuclear activity[9]. These precautions allow the IAEA to detect the diversion of nuclear materials to an undisclosed weapons program. For example, swipe samples of surfaces in a uranium enrichment plant can be analyzed to determine if natural or low enriched uranium is being enriched to HEU. The goal of this monitoring is to be able to detect if a country has decided to breach its NPT commitments and pursue a nuclear weapon early enough that an international response can be mounted.

Iran's Nuclear Program Iran's nuclear program dates back to the 1950s[10]. Under President Eisenhower's Atoms for Peace program, the United States signed a nuclear cooperation deal with Iran. This led to the United States supplying Iran with the Tehran Research Reactor, which is still in operation today. Iran's nuclear program expanded with the development of a centrifuge enrichment program and a heavy water nuclear reactor[11]. Iran acquired designs for uranium centrifuges from the A.Q. Khan smuggling network[7]. Centrifuges, based on these designs, were put into mass production and served as the basis for the development of more advanced designs. There are two sites where the centrifuge program was based, Natanz and Fordow. The Natanz site, the existence of which was revealed in 2002, has a fuel enrichment plant and a pilot enrichment plant which in 2015 had over 16,000 installed centrifuges[11,12]. The Fordow site, built into a mountain and not revealed until 2009, housed an additional 2,700 centrifuges by 2015[12]. At the Natanz site, the majority of the centrifuges were utilized to enrich uranium to $3.5 \%$, suitable for use in a commercial power reactor[11]. In addition to this, at the Fordow site, and in the pilot enrichment plant at Natanz, uranium was also enriched to $20 \%[11]$. The Tehran 
research reactor requires fuel of this enrichment to operate, but stockpiling $20 \%$ enriched uranium would also significantly reduce the amount of work required to create weapons-grade material[7]. In addition to its centrifuge facilities, in 2004, Iran started to build a heavy water reactor at the Arak site which could produce plutonium from natural uranium. Iran's contention was that this would be utilized to produce medical isotopes, but it also had the capability to produce enough plutonium for two nuclear weapons per year[11].

Much of Iran's development work on nuclear technology was not reported to the IAEA, as was required under their safeguards agreement[11]. Iran also conducted preliminary research into technologies which are non-nuclear but are required for the construction of a nuclear weapon[13]. These include early development and experiments required to properly design a working nuclear weapon as well as ways to mount a nuclear weapon onto ballistic missiles[13].

Starting in 2002, the IAEA investigated the Iranian nuclear program for its possible military dimensions[14]. The IAEA found Iran in non-compliance with its safeguard commitments in 2005 and in 2006 referred the case to UN Security Council. This eventually led to six Security Council resolutions regarding Iran's nuclear program[14]. Ultimately, concerted economic sanctions on the Iranian economy from the United States, United Nations, and European Union put pressure on Iran to come to a negotiated international agreement[15].

The JCPOA By 2013, Iran had reached an interim agreement with the five members of the UN Security Council (US, Russia, China, France, and the UK) and Germany (P5+1) outlining initial steps that Iran would take regarding its nuclear program in exchange for reduced sanctions. A final, more extensive agreement was reached in 2015, called the Joint Comprehensive Plan of Action. This agreement saw Iran accept limits on a number of the more proliferation-sensitive aspects of their nuclear program and accept more stringent verification and reporting procedures to demonstrate their adherence to the agreement[11]. These provisions would be in place for up to 15 years. It also required Iran to accept and implement an additional protocol, which would remain in force indefinitely.

Under the terms of the agreement, Iran was limited to operating 5,060 centrifuges, half of the number it previously was operating. All uranium enrichment was ceased at the Fordow site and decommissioned centrifuges were stored under IAEA seal at Natanz[11]. The development of advanced centrifuges was limited to experiments on single centrifuges of four different designs for the first 8 years of the deal, with restrictions loosening thereafter. Uranium enrichment was capped at $3.67 \%$ and Iran was allowed to possess a stockpile of no more than $300 \mathrm{~kg}$ of enriched material. The core of the heavy water reactor was destroyed by filling it with cement, and in its place was to be built a redesigned reactor that would be unsuitable for producing plutonium[11]. Limits were also placed on the amount of heavy water that Iran could possess and Iran committed to shipping their spent fuel out of country, preventing extraction of plutonium from the fuel. In addition to these technical steps, Iran also acceded to the Additional Protocol, which gives the IAEA additional authorities to inspect sites.

In sum total, the reduction in the number of centrifuges and the limits on the stockpile of enriched material were designed to extend the amount of time that it would take Iran to produce enough HEU for a weapon from 2-3 months to twelve months[11]. It also closed the plutonium pathway by irreversibly converting the Arak reactor to a proliferation resistant design. The increased IAEA presence, with an indefinite duration, continues to make it more difficult for Iran to cease compliance with any of its obligations without detection[16]. For Iran to develop a covert weapons program, they would need to surreptitiously create supply chains in parallel to their declared program. An establishment capable of developing a nuclear weapon cannot be built overnight, and would likely require material or expertise to be diverted from their declared program. If Iran's greatest nuclear minds were diverted to a covert weapons program, having the Additional Protocol in force puts the IAEA in a better position to note their absence.

Current Status of the JCPOA On May 8, 2018, President Trump announced that the United States was withdrawing from the Joint Comprehensive Plan of Action due to a belief that the deal "fail[s] to halt Iran's nuclear ambitions...fails to address the regime's development of ballistic missiles that could deliver nuclear warheads...[and] does nothing to constrain Iran's destabilizing activities, including its support for terrorism"[17]. In addition to withdrawing from its commitments under the JCPOA, the Trump Administration reinstated severe economic sanctions on Iran.

These sanctions were not supported by the other signatories to the JCPOA. In response, European Union countries established the "Instrument in Support of Trade Exchanges" to facilitate financial transactions with Iran that bypass the U.S. sanctions. To date, the financial mechanism has only been used to support the export of medical goods to Iran in response to the COVID-19 pandemic. Despite continued European interest in maintaining the deal, in response to American withdrawal from the JCPOA, on May 8, 2019, Iran announced that its government had "issued an order to stop some of Iran's measures under the JCPOA," including those related to uranium enrichment and reserves of heavy water[18].

The International Atomic Energy Agency (IAEA) continues to perform verification and monitoring of Iranian nuclear activities, including containment and surveillance measures. As of June 5, 2020, the IAEA has reported that Iran has exceeded limits on stocks of heavy water that were allowed under the JCPOA, started $\mathrm{UF}_{6}$ enrichment at Natanz and Fordow up to $4.5 \%{ }^{235} \mathrm{U}$, exceeded limits on its enriched uranium stockpile to over five times the allowed quantity, and begun using advanced centrifuges for enrichment[19]. In addition, on November 7, 2019, the IAEA detected "natural 
uranium particles of anthropogenic origin" at an undeclared facility in Iran following disclosure by the Israeli government. This facility indicates the potential continued presence of a military nuclear program and Iran has yet to provide explanation to the IAEA about its origins.

While Iran is still subject to the additional protocol which allows expanded access to civilian facilities, the limits on uranium stockpile size and number of operating centrifuges are no longer in place. Maintaining a stockpile of LEU and having a capability to enrich uranium are not activities inherently in breach of the NPT as, when subject to safeguards, they could be used purely in support of a peaceful civilian nuclear program. However, regaining this capability would place Iran in a position where, upon making a political decision to build a weapon, could "break out" and utilize this civilian stockpile and capability to manufacture a nuclear weapon[11]. The JCPOA was estimated to have extended the breakout time from approximately 2-3 months to 12 months. As of March 2020, the breakout time was estimated to be 4 months[20].

\section{Policy Options}

Nuclear nonproliferation has been a U.S. strategic goal since the end of the second world war. The JCPOA, which placed limits on Iranian nuclear activities above and beyond those laid out in the NPT, is no longer being observed by the United States or Iran. If U.S. lawmakers are to continue to pursue the strategy of preventing nuclear proliferation, they have a number of policy options available to them to limit the Iranian nuclear program.

- Maximum pressure campaign including economic sanctions. The current policy dubbed "maximum pressure" which relies on utilizing economic sanctions includes goals to limit Iran's destabilizing non-nuclear activities and to incentivize Iran to maintain compliance with JCPOA limits without reciprocal U.S. compliance to the deal.

- Military Action Military action, ranging from covert cyber attacks to bombing missions against Iranian sites to a full-scale ground war, could remove Iran's capability to develop nuclear weapons, though at great risk and cost.

- Return to the JCPOA or similar diplomatic agreement. A new or renewed agreement would entail several diplomatic steps by the U.S. likely including removing economic sanctions and refraining from hindering the Iranian economy.

\section{Analysis of Options}

Maximum Pressure To date, the Trump Administration has focused on a "maximum pressure campaign" of economic sanctions designed, among a number of goals, to limit the Iranian government's financial resources to pursue nuclear weapons and compel Iran to negotiate a broader deal which encompasses their non-nuclear activities[15]. In 2019, following U.S. reinstatement of additional economic sanctions, the Iranian economy contracted by $9.5 \%[21]$ after growing at an annual rate of $12.5 \%$ following the removal of sanctions under the JCPOA[22].

Despite the clear effects on the Iranian economy, the effectiveness of these sanctions in the short-term on reducing Iran's desire to pursue nuclear weapons has not been demonstrated. Academic arguments can be found on both sides regarding the effectiveness of sanctions against non-democratic societies[23], but the logic of the Trump Administration is two-fold: (i) limit Iranian financial ability to maintain a nuclear weapons program and (ii) generate civil unrest that could result in regime change. Given the unilateral nature of the U.S. withdrawal from the JCPOA, the European Union has sought to circumvent the new U.S. sanctions in order to encourage Iran to continue to abide by the accord[15]. This was ineffective however, and Iran announced that it viewed itself as no longer being bound by the terms of the agreement. In order for the maximum pressure campaign to prevent Iran from being able to quickly "break out" and develop a weapon on short notice it must either bring about regime change, reduce Iran's financial ability to support their nuclear program, or spur Iran to accede to a larger deal that encompasses their ballistic missile program and regional support for militants.

Economic sanctions have influenced countries behaviors and induced regime change in the past, but they have been most effective when coordinated internationally, for a highly specific purpose, with unambiguous conditions on their removal as soon as that purpose is met. Unilateral sanctions have not been as effective. Economic sanctions have the added cost of extracting a significant humanitarian toll from civilians[24]. Additionally, the case of North Korea demonstrates the ability of an autocratic regime to develop a nuclear weapons program under severe economic pressure[25].

Economic sanctions could also serve as the impetus for a larger negotiated agreement that addressed Iran's ballistic missile program and regional support for militants in addition to its nuclear program. U.S. Secretary of State Michael Pompeo issued a list of twelve demands, four of which are related to non-proliferation, for the Iranian regime in order for the United States to be willing to negotiate a new agreement[26]. These included "a full account of the prior military dimensions of its nuclear program," a commitment to "never pursue plutonium reprocessing," and an agreement to "provide the IAEA with unqualified access to all sites throughout the entire country." The Intermediate-Range Nuclear Forces treaty, a Cold War-era bilateral agreement between the United States and Russia to eliminate an entire class of nuclear-capable ballistic missiles, demonstrates that there is a model for an arms control agreement to limit the development of ballistic missile programs in a verifiable way[27]. Verifying cessation of support for militant groups may be more complicated and would likely rely on intelligence services to monitor. 
The larger challenge in reaching a more comprehensive deal is bringing Iran to the table. Iran may fear a slippery slope in submitting to further limitations, making an expanded agreement a political non-starter. By unilaterally withdrawing from the JCPOA, the United States will have less credibility in future negotiations, especially if a future deal is an executive agreement like the JCPOA and not voted on by the U.S. Senate. Further, because the international community is no longer united on a path forward, exerting consistent pressure on Iran may be difficult[15]. Although the technical capabilities to make a verifiable agreement that included the Iranian ballistic missile program exist, the primary challenges will be political in nature.

Military Action In the past, military actions, ranging from invasion to physical attacks against specific sites to cyber attacks have been considered or used to hinder a country's ability to develop nuclear weapons. Each option has a different cost in terms of lives, materiel, and international political capital, all of which must be carefully considered. While the Iran situation is unique, there are several historical instances where military force has been considered or used as a means of prevent nuclear weapon development. These events serve as some of the only case studies of the results of the use of force as a means of counter-proliferation, and a useful method to examine potential use of United States military action as a policy option.

1) Targeted Attacks Against Nuclear Program Sites: In June of 1981, believing that the government of Iraq was planning to produce nuclear weapons, the Israeli air force bombed an Iraqi light water reactor[28]. Some scientists posit that this attack set back the Iraqi nuclear program by roughly fifteen years, while others says the design of the Osirik reactor coupled with the low quantity of uranium present in Iraq meant that the destruction had no significant impact on plutonium production for a nuclear weapon[29]. Regardless of the immediate implications this attack had on an Iraqi nuclear weapons program, the international response was nearly unanimously critical of the Israeli action.

Unilateral kinetic action tends to generate negative or counterproductive reactions in the international community, and this event proved no different. Led by France, who provided the Iraqis with technical assistance at the reactor, countries around the world, including the United States condemned the attack, culminating in a United Nations Security Council Resolution censuring Israel[30]. In addition, this attack served as a motivation for continued development of a nuclear program, because it proved to the government of Iraq that becoming a nuclear power would generate additional political leverage. Indeed, after this event, the Iraqi government poured tens of millions of dollars into a weapons development program, and received covert assistance from the Soviet Union in doing so[31].

We can contrast this with an attack on a suspected Syrian reactor site in 2007. In a similar manner to the Osirik attack, the Israeli air force bombed a Syrian nuclear facility at AI Kibar.
This facility, unlike the Osirik reactor, was being constructed without any acknowledged foreign assistance, and likely for the purpose of producing nuclear weapons, based on later announcements from the IAEA and intelligence linking North Korean nuclear scientists with the site[32,33]. In part due to the direct connections to a nuclear weapon program, this attack did not generate a widespread negative international reaction, and likewise did not spur the continued development of a nuclear program. At the present, Syria possesses no nuclear weapons, but because of the Syrian civil war, it is difficult to fully understand the impact this air strike had on weapons development.

In all, the attack on the Osirik reactor was unilateral, of debatable effectiveness, and resulted in a strong negative international reaction, whereas the attack on the Syrian reactor, while also unilateral, received much less negative condemnation. Also of note, neither of these states had the ability to launch significant, damaging counter attacks that that could spiral into regional conflict. In Iraq, for instance, the air force was occupied and degraded by the war with Iran whereas, a 2012 study by the Center for Strategic and International Studies suggests that an attack on Iran would result in asymmetric response from Iran, including missile strikes on American forces in the Middle East, potential strikes on Israeli population centers if Israeli was implicated in the attack, and the closure of the Straits of Hormuz[34]. We can contrast this with the present situation in Iran and suggest that targeted attacks against the Iranian nuclear program would likely generate moderate to strong negative international reaction, potentially incite a counter attack, and though it may result in slowing the nuclear program in the short term, be of debatable effectiveness in the long term.

2) Ground War: Military invasions have been considered in the past as a means of countering proliferation. In 1994, the Clinton administration considered the use of force against the Democratic People's Republic of Korea to halt their nuclear program. Ultimately, the administration did not launch an invasion, recognizing that the military capabilities and ideologies of North Korea would potentially result in massive military and civilian casualties[35].

While counter-proliferation was not a primary objective of the first Gulf War, the massive military and economic damage suffered by Iraq effectively ended its nuclear weapons program[36]. The ground war cost between thirty and fifty thousand soldier's lives and approximately five thousand civilian deaths between both sides, and over one hundred billion dollars in monetary costs[37,38]. We can use the first Gulf War as a rough model to contrast the Iranian breakout time with the timeline of a build up of U.S. military forces in the Middle East and subsequent incursion. From the invasion of Kuwait by Iraqi forces in August of 1990 to the cessation of hostilities in February 1991, roughly seven months elapsed[39,40]. Current estimates place Iranian breakout time at roughly 4 months. Even if we assume that a ground invasion of Iran, which is geographically much larger than Iraq, could be conducted in, at best, a similar amount 
of time, there would be a window of time where a threatened Iran could decide to pursue a nuclear weapon in an attempt to deter invasion. As such, in addition to the costs in terms of lives and money that a ground invasion of Iran would impose, pursuing it would run the risk of hastening the development of an Iranian nuclear weapon.

3) Covert Military Action: In contrast to a direct military strike on a nuclear program, the United States could also take more covert actions towards non-proliferation, employing cyber-weapons. In 2010, the destruction of roughly 1000 centrifuges at the Natanz facility in Iran was attributed to the Stuxnet computer worm[41]. The effectiveness of the worm on Iran's nuclear program is debatable, since production of enriched uranium at the Natanz facility in fact increased in 2010 , but the rate of increase may have been limited by the virus[42]. However, use of the virus generated none of the negative political reactions associated with military actions, had a much lower price point (in the millions of dollars), and the employment had a significantly lower chance of collateral damage[41]. Further employment of cyber-weapons as a means of non-proliferation appears to be a relatively low-risk/low-reward situation for the United States.

JCPOA-like Diplomatic Agreement The JCPOA, while departed from in significant parts by the United States and Iran, still remains an effective framework from which to base negotiations. The additional limits placed on Iranian nuclear material and enrichment capability significantly extended the time that it would take Iran to develop a nuclear weapon[11]. Reverting to this state is generally favored by the American public, roughly three fifths of Americans supported the JCPOA in 2018 , and four fifths supported some diplomatic resolution generally speaking[43]. The Iranian public would support a return to full compliance and further negotiations on the conditions that the U.S. return to the JCPOA, economic sanctions being eased, and the $\mathrm{P} 5+1$ being recognized as the sole venue for negotiations[44]. The deal was regarded as effective by high ranking former members of the United States Departments of State and Defense, as well as notable scientists in the nuclear field, though some, most notably in the DoD, believe the deal was ineffective. However, American (and EU) credibility was severely weakened following the backing away from the deal. Reverting to the original deal would be difficult. The U.S. would need to remove sanctions while Iran would need to walk back it's nuclear program to comply with the JCPOA limits but neither side would want appear to be making concessions. Thus, while it was generally regarded as an effective non-proliferation tool, returning to the JCPOA status quo is a difficult task, due to the changed nature of the situation.

Returning to the agreement would require that the U.S. return to the P5+1 which would need to be recognized as the sole venue for any further negotiations. In additions to the removal of sanctions which were put in place after the U.S.'S unilateral withdrawal from the agreement, the U.S. would more generally need to refrain from interfering with the Iranian economy while Iran remained in compliance. The Iranians would need to roll back activities which breach the limits of the JCPOA which have been ramped up since U.S. withdrawal. To save face, the process would likely need to be step-by-step and reciprocal making incremental steps toward returning to the agreement, and perhaps coordinated quietly through diplomatic channels. While these would be a major diplomatic lift, a return to the JCPOA limits on Iranian nuclear activities would increase breakout time and constitute a meaningfu limitation on their capability to develop a nuclear weapon.

\section{Conclusions}

Since Iran violated its NPT agreements prior to 2003 , a major international effort has been made to limit the ability of Iran to develop a nuclear weapon if it chose to do so. The Iran deal placed additional limits on Iranian nuclear activities which extended the amount of time which it would take Iran to develop a nuclear weapon from a few months to roughly a year. Since unilateral U.S. withdrawal from the agreement in 2018, Iran has resumed some of these activities and estimates of breakout time have decreased to roughly 4 months. The faster that Iran is able to break out and develop a weapon, if it chose to do so, the less time there would be to detect the infraction and mount a response.

The U.S. has a handful of policy options which have the potential to prevent Iran from being able to go nuclear. (i) a continued reliance on economic sanctions as part of the maximum pressure campaign which seeks to limit Iran's financial capability to support a nuclear program. (ii) military actions, from targeted attacks to invasion, each of which having grave costs and accepting risks of pushing Iran further toward nuclear weapons. (iii) A return to compliance with the JCPOA which would present diplomatic challenges but places known limitations on Iranian nuclear capability.

\section{Acknowledgements}

The authors would like to thank MIT and the reviewers for helpful feedback.

\section{Citation}

MacDonald et al. Our Remaining Options for Preventing a Nuclear Iran. MIT Science Policy Review 1, $92-98$ (2020).

\section{Open Access}

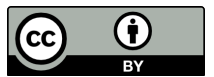

This MIT Science Policy Review article is licensed under a Creative Commons Attribution 4.0 International License, which permits use, sharing, adaptation, distribution and reproduction in any medium or format, as long as you give appropriate credit to the original author(s) and the source, provide a link to the Creative Commons license, and indicate if changes were made. The images or other third party material in this article are included in the article's Creative Commons license, unless indicated otherwise in a credit line to the material. If material is not included in the article's Creative Commons license and your intended use is not permitted by statutory regulation or exceeds the permitted use, you will need to obtain permission directly from the copyright holder. To view a copy of this license, visit http://creativecommons.org/licenses/ 
$\mathrm{by} / 4.0 /$.

\section{References}

[1] Norris, R. S. \& Kristensen, H. M. Global nuclear weapons inventories, 1945-2010. Bulletin of the Atomic Scientists 66, 77-83 (2010).

[2] Sagan, S. D. The causes of nuclear weapons proliferation. Annual Review of Political Science 14, 225-244 (2011).

[3] Kristensen, H. M. \& Norris, R. S. Status of world nuclear forces. Federation of American Scientists (2017).

[4] Fetter, S. et al. Detecting nuclear warheads. Science \& Global Security 1, 225-253 (1990).

[5] Agency, N. E. \& Agency, I. A. E. Uranium 2018 (2019). URL https://www.oecd-ilibrary.org/content/ publication/uranium-2018-en.

[6] Narang, V. Strategies of nuclear proliferation: How states pursue the bomb. International Security 41, 110-150 (2017)

[7] Kemp, R. S. The nonproliferation emperor has no clothes: the gas centrifuge, supply-side controls, and the future of nuclear proliferation. International Security 38, 39-78 (2014).

[8] Rockwood, L. Legal framework for iaea safeguards (2013).

[9] Donohue, D. Strengthening iaea safeguards through environmental sampling and analysis. Journal of Alloys and Compounds 271, 11-18 (1998).

[10] Homayounvash, M. Iran and the Nuclear Question: History and Evolutionary Trajectory (Routledge, 2016).

[11] Davenport, K., Kimball, D. G. \& Thielmann, G. Solving the iranian nuclear puzzle: The joint comprehensive plan of action. Arms Control Association Briefing Book, August (2015).

[12] General, D. Implementation of the npt safeguards agreement and relevant provisions of security council resolutions in the islamic republic of iran. IAEA Board of Governors (2011).

[13] General, D. Final assessment on past and present outstanding issues regarding iran's nuclear programme. IAEA Board of Governors (2015).

[14] Kerr, P. K. Irans nuclear program: Tehrans compliance with international obligations. Tech. Rep., Congressional Research Service Washington United States (2016).

[15] Katzman, K. Iran sanctions. crs report. washington, dc: Congressional research service (2016).

[16] Kerr, P. K. \& Katzman, K. Iran nuclear agreement and us exit (Congressional Research Service,[Library of Congress], 2018).

[17] Trump, D. J. Remarks by President Trump on the Joint Comprehensive Plan of Action (2018). URL https://www. whitehouse.gov/briefings-statements/remarkspresident-trump-joint-comprehensive-planaction/.

[18] Supreme National Security Council of Iran. Iran stops some of its measures under JCPOA (2019). URL http://president. ir/en/109588.

[19] IAEA Board of Governors. Verification and monitoring in the Islamic Republic of Iran in light of United Nations Security Council resolution 2231 (2015). Tech. Rep., International Atomic Energy Agency, Vienna, Austria (2020). URL https://www.iaea.org/sites/default/files/20/ $06 /$ gov2020-26.pdf.

[20] Albright, D. \& Burkhard, S. Iranian Breakout Estimates and Enriched Uranium Stocks. Tech. Rep., Institute for Science and International Security, Washington, D.C. (2020). URL https: //isis-online.org/isis-reports/detail/iranianbreakout-estimates-and-enriched-uranium-stocks.

[21] Six charts that show how hard US sanctions have hit Iran (2019). URL https://www.bbc.com/news/world-middle-east48119109.

[22] Central Bank of the Islamic Republic of Iran. Annual Report 2016/17 (2017). URL https://www.cbi.ir/page/17602. aspx.
[23] Beinart, P. How Sanctions Feed Authoritarianism. The Atlantic (2018). URL https://www.theatlantic.com/ international/archive/2018/06/iran-sanctionsnuclear/562043/.

[24] Marinov, N. Do economic sanctions destabilize country leaders? American Journal of Political Science 49, 564-576 (2005).

[25] Kristensen, H. M. \& Norris, R. S. North korean nuclear capabilities, 2018. Bulletin of the Atomic Scientists 74, 41-51 (2018).

[26] Pompeo, M. R. After the Deal: A New Iran Strategy (2018). URL https: //www.state.gov/after-the-deal-a-newiran-strategy/.

[27] Kimball, D. \& Reif, K. The intermediate-range nuclear forces (inf) treaty at a glance. Arms Control Association (2016).

[28] Shipler, D. K. Israeli jets destroy iraqi atomic reactor. The New York Times 1,8 (1981). URL https://timesmachine. nytimes.com/timesmachine/1981/06/09/149836. html?pageNumber=1.

[29] Reiter, D. PREVENTIVE ATTACKS AGAINST NUCLEAR PROGRAMS AND THE "SUCCESS" AT OSIRAQ. The Nonproliferation Review 12, 355-371 (2005). URL https: /doi.org/10.1080/10736700500379008.

[30] United Nations Security Council. Resolution 486 (1981).

[31] Tamsett, J. The israeli bombing of osiraq reconsidered: Successful counterproliferation? The Nonproliferation Review 11, 70-85 (2004). URL https://doi.org/10.1080/ 10736700408436979

[32] Perino, D. Statement by the Press Secretary (2008). URL https://georgewbush-whitehouse.archives.gov/ news/releases/2008/04/20080424-14.html.

[33] General, D. Implementation of the npt safeguards agreement in the syrian arab republic (2012)

[34] Cordesman, A. H. \& Toukan, A. Analyzing the Impact of Preventive Strikes Against Iran's Nuclear Facilities (2012).

[35] Kim's nuclear gamble (2003).

[36] Albright, D. Iraq's program to make highly enriched uranium and plutonium for nuclear weapons prior to the gulf war. The Institute for Science and International Security (2002).

[37] Daggett, S. Costs of Major U.S. Wars (Congressional Research Service, 2011).

[38] Larson, E. V. \& Savych, B. Misfortunes of war: Press and public reactions to civilian deaths in wartime (Rand Corporation, 2007).

[39] War in the persian Gulf Operations Desert Shield and Desert Storm August 1990-March 1991 (United States Army Center of Military History, 2010)

[40] Rayburn, C. J. D. \& Sobchak, C. F. K. The US Army in the Iraq War (United States Army Center of Military History, 2019).

[41] Daggett, S. Stuxnet Facts Report: A Technical and Strategic Analysis (NATO Cooperative Cyber Defence Centre of Excellence, 2012).

[42] Barzashka, I. Are cyber-weapons effective? The RUSI Journal 158, 48-56 (2013). URL https://doi.org/10. 1080/03071847.2013.787735. https://doi.org/10. $1080 / 03071847.2013 .787735$.

[43] Russonello, G. How the public feels about trump's iran strategy. The New York Times (2020). URL https: //www.nytimes.com/2020/01/10/us/politics/trumpiran-polls.html.

[44] Gallagher, N., Mohseni, E. \& Ramsay, C. Iranian Public Opinion under "Maximum Pressure" (2019). 